\title{
XVI. On a new insulating support
}

\section{Professor Silvanus P. Thompson B.A. D.Sc.}

To cite this article: Professor Silvanus P. Thompson B.A. D.Sc. (1884) XVI. On a new insulating support , Philosophical Magazine Series 5, 17:104, 134-135, DOI: $10.1080 / 14786448408627491$

To link to this article: http://dx.doi.org/10.1080/14786448408627491

$$
\text { 册 Published online: } 29 \text { Apr } 2009 .
$$

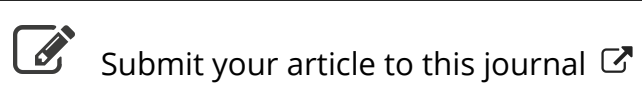

\footnotetext{
Џll Article views: 2
}

Q View related articles $₫$ 
for which, from (39), we may also write

$$
v_{0}=\frac{a b \mathbf{R}}{p b+q-a b p} \cdot \text {. . . . }
$$

The value of $v_{0}$ expresses the number of what are called the dead turns.

I reserve for a future paper further applications of the chief equations developed in this paper, more especially to the transmission of force by dynamo-electrical machines.

XVI. On a new Insulating Support. $B y$ Professor Srlvanus P. Thompson, B.A., D.Sc.*

[Plate IIII.]

TNSULATING supports consisting of rods rising through 1 the necks of glass jars containing concentrated sulphuric acid, for the purpose of absorbing moisture which otherwise would condense upon the glass, appear to have been first introduced in practice by Sir William Thomsont. Similar devices have been more recently designed by Mascart $\ddagger$, by Professor Clifton $\S$, and by Professors Ayrton and Perry. The ap aratus of Mascart differs only from the original design of Sir W. Thomson in having the central support of glass solidly fused to the bottom of the jar which holds the acid, and in having the jar formed with a narrow neck instead of a wide one. This construction, though convenient in point of portability and solidity, render's necessary the addition of a tubulure at the side of the vessel by which to introduce the acid. The cost of the apparatus, which cannot be made except by a professional glass-blower, is consequently considerable.

Such supports are, in spite of their cost, of so great utility, especially in a humid climate, that a cheaper substitute of equally high insulation is a desideratum. In the electrical laboratory of University College, Bristol, insulating supports of the type about to be described are found of very great use.

A piece of combustion-tube, about 20 centim. long and 1.4 centim. diameter, is fused together at one end, and the closed end is slightly enlarged by blowing, and then slightly flattened at its extremity. This tube, which forms the central support,

* Communicated by the Physical Society; read December 8, 1883.

+ Proc. Roy. Soc. June 1867, and 'Reprint of Papers on Electrostatics and Magnetism,' p. 322. See also the figure given on page 14 of Maxwell's 'Elementary 'Treatise on Electricity.'

† Journal de Physique, t. vii. p. 217 (1878); 'Nature,'xviii. p. 44 (1878); see also Wiedemann's Electriçtät, Bd. i. p. 16.

$\S$ Proc. Roy, Soc. No. 182, p. 300 (1877). 
Phil. Mag. S. 5.Vol. 17. P1. III.

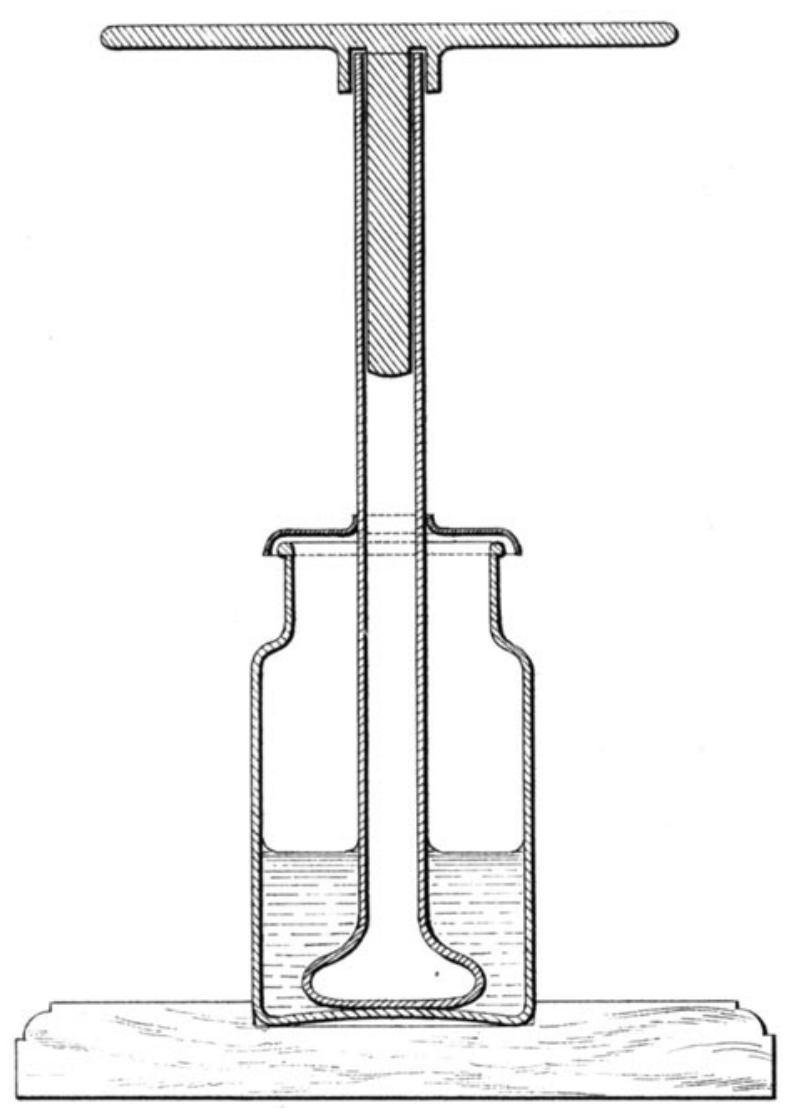

Fig.1.

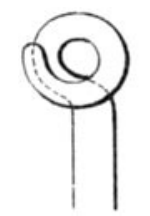

Fig. 2

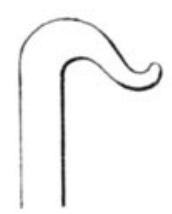

Fig.3.

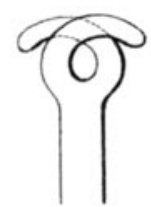

Fig.4.

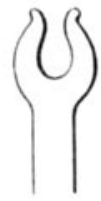

Fig. 5.

Seale $\frac{1}{2}$. 
is placed upright in a wide-mouthed bottle of hard white flintglass about 10 centim. high and 5.5 centim. diameter, in which about 50 to 70 grammes of paraffin-wax have been melted. When the paraffin solidifies it contracts greatly; but if the bottle be not too large, holds the stem firmly in its place. To keep out the dust a lid, formed from a disk of gutta-percha about 2 millim. thick, softened by dipping into boiling water, is placed loose-tight on the stem. The arrangement is shown in fig. 1. The upper end of the central tube is open, and affords a convenient means of placing on the support various different objecis, such as a metal ball fixed on a metal rod, or a flat metal plate on which to stand any object that is to be insulated. For carrying wires over a table in experiments requiring high insulation, rods of flint-glass of 25 to 30 centim. length, curled at the top in the form of a crook or other hookform, as shown in figs. 2 to 5 , are placed in the central tube of the insulating support, and the wires are slung in them. The insulation-resistance of these supports is maily bundreds of megohms even in damp weather. Should a film of dust accumulate on the surface of the paraffin in consequence of any neglect in lowering the gutta-percha cap, the insulator only requires to be warmed to the melting-point of paraffin to restore the lost insulation. For work requiring very special insulation, sulphuric acid is poured over the top of the paraffin; and in some cases solid ste-ns of glass have been used instead of glass tube. Hitherto there has been no trouble from yielding in the paraffin, which was feared at the outset as a possible fault. A good hard paraffin has been used; and as the flattened form given to the basal enlargement of the glass tube constitutes in itself a foot to the central support, there is little or no tendency for the paraffin to bend under the weight that may be placed for a few hours on the top of the support. To add stability to the apparatus, the bottle is let into a wooden foot. The total cost of the apparatus is less than one tenth of the price charged for the apparatus of Mascart.

XVII. On the Reduction of Observations. By F. Y. EDGEworth, M.A., Lecturer on Logic at King's College, London*.

TN an article on the Method of Least Squares which lately 1 appeared in this Journal† I attempted to answer two questions-first, why is one mode of reducing observations to bo preferred to another, and, secondly, what is the preferable mode in certain important cases. The answer to the first

* Communicated by the Author.

+ November 1883. 